UDC 947(470.6)«1990»:323.13

Submitted: 27.03 .2016

LBC 63.3(2Poc-13)634-283.31

Accepted: 15.09 .2016

\title{
THE COSSACK RESTORATION MOVEMENT IN THE SOUTH OF RUSSIA IN THE EARLY 1990S: ORGANIZATION, IDEAS AND PARTICIPANTS
}

\author{
Olga V. Rvacheva \\ Volgograd Branch of the Russian Presidential Academy of National Economy and Public Administration, \\ Volgograd, Russian Federation
}

\begin{abstract}
In the early 1990s first Cossack organizations were formed in Russia and the process of Cossack restoration was launched. The role of the government was very important in the organization of the Cossack restoration movement and in forming its bodies. Nevertheless, initially the movement was pushed mostly by aspiration of Cossack descendants, i.e. by primarily social and cultural forces. In the first place those forces searched for a new social identity and the desire to regain the Cossacks' past and, probably, to live it again. The Cossack restoration movement is developing in many regions of Russia. The process is especially rapid in the south of Russia, on the traditional Cossack territories which were part of the Don, Terek, Kuban, and Astrakhan Cossack Hosts in the early 20th century. New Cossack organizations are formed by people of different professions and social status, Cossack organizations grow fast in number which is indicative of demand for Cossack movement in the Russian society. The principal ideas under the Cossack restoration movement are preservation of the Cossack culture and history, rehabilitation of the Cossacks as a politically persecuted people and its ethnic revival, and presentation of the Cossacks as the most patriotic part of the Russian society. These principal ideas vary in details in different Cossack organizations according to the changed social, territorial, and political conditions. Nevertheless, all the above-mentioned factors collectively led to establishing the Cossacks as a new distinct part of the Russian society and contributed to putting the Cossack restoration movement on a long-term basis in the social and political life in Russia.
\end{abstract}

Key words: South of Russia, Cossacks, history, culture, restoration, organization, participants, movement ideas.

УДК 947(470.6)«1990»:323.13

ББК 63.3(2Poc-13)634-283.31

Дата поступления статьи: 27.03.2016

Дата принятия статьи: 15.09.2016

\section{ДВИЖЕНИЕ ЗА ВОЗРОЖДЕНИЕ КАЗАЧЕСТВА НА ЮГЕ РОССИИ В НАЧАЛЕ 1990-Х ГГ.: ОРГАНИЗАЦИОННЫЕ ФОРМЫ, ИДЕИ И УЧАСТНИКИ ПРОЦЕССА}

\section{Ольга Владимировна Рвачева}

Волгоградский филиал Российской академии народного хозяйства и государственной службы при Президенте Российской Федерации, г. Волгоград, Российская Федерация

\footnotetext{
Аннотация. В конце 1980-х - начале 1990-х гг. в России формируются первые казачьи организации и начинается процесс, получивший название «возрождение казачества». Несмотря на то, что большую роль в развитии возрожденческого процесса сыграло государство, придав движению организационную форму и сформировав управление, на начальном этапе своего развития движение отвечало запросам со стороны отомков казаков и формировалось под воздействием прежде всего причин, имеющих социальный и куль保 чества развивалось во многих регионах России. На Юге России, на территориях традиционного проживания казачества, в начале XX века входивших в состав Донского, Терского, Кубанского и Астраханского войск, возрождение казачества происходило особенно стремительно. В формирующиеся казачьи организации при(2) ходили люди различных профессий и социальных статусов, в короткие сроки движение стало массовым, что
} 
свидетельствовало о востребованности возрождения казачества обществом. Основными идеями казачьего возрождения становятся возрождение и сохранение культуры и истории казаков, правовая и социальная реабилитация казачества как репрессированного народа и его этническое возрождение, а также манифестация казачества как наиболее патриотической части российского общества. В связи с тем, что современные казачьи общества развивались в новых социальных, территориальных и политических условиях, основные идеи казачьего возрождения в каждом из них имели специфичную форму и содержание. Однако в совокупности все это способствовало закреплению казачества в его новой форме в российском обществе и долгосрочному присутствию феномена казачьего возрождения в социально-политической жизни нашей страны.

Ключевые слова: Юг России, казачество, история, культура, возрождение, организация, участники, идеи движения.

В конце 1980-х - начале 1990-х гг. в России началось движение за возрождение казачества. Практически сразу движение попало в фокус внимания политических и властных структур, которые стали предлагать участникам казачьего движения различные формы взаимодействия. Важная роль государства и его заинтересованность в казачьем возрождении отмечалась не раз. Высказывались мнения, что в период зарождения движения за возрождение казачества в конце 1980-х гг. советско-партийные органы в регионах не только получали инструкции по отслеживанию деятельности казачьих организаций, но и напрямую ими руководили. В качестве примеров приводились цифры о количестве партийных и советских работников в правлениях казачьих обществ $[17$, с. $62 ; 24$, с. 64$]$.

Однако, на наш взгляд, не стоит преувеличивать роль государства в казачьем возрождении, особенно на начальном этапе его развития. В конце 1980-х гг., в условиях кризиса советской системы, поиска обществом новых политических, социальных и культурных основ, в казачье движение нередко приходили люди, искренне верившие в возможность возрождения казачества в новой России и считавших, что казаки заслужили особого отношения к себе со стороны власти. Деятельность этих первых участников движения за возрождение казачества привела не только к организационному оформлению движения, формированию правового поля казачьего возрождения, но и к тому, что сегодня казачество, особенно на Юге России, вновь стало неотъемлемой частью социально-политической жизни, ее субъектом.

Изучение процесса возрождения казачества неизменно сталкивается с проблемой методологического осмысления феномена «возрождение казачества», заключающейся, во-первых, в трактовке термина «возрождение» применительно к казачеству, а во-вторых, в попытке концептуального определения, что же должно быть возрождено и что происходит на самом деле. У специалистов в истории казачества наблюдается довольно большой разброс мнений по данному вопросу. В историческом контексте трактовки возрождения как восстановления того, что уже когда-то было, рассматривает процесс В.П. Трут, определяющий возрождение как «самовосстановление казачества» [25, с. 18]. О естественно-исторической природе возрождения говорит и определение его как «воскрешения» по аналогии с ситуацией Ренессанса, данное А.И. Козловым [12, c. 135-145]. О возрождении как о восстановлении того, что было разрушено, но с элементами новизны, обновления пишут А.П. Скорик и Р.Г. Тикиджьян [8, с. 374-375].

Философско-социологическая трактовка возрождения казачества позволяет рассматривать его как реализацию социального проекта по созданию казачьей корпорации (А.П. Скорик) [22], социальную реконструкцию (Г.П. Астапенко) [4, с. 14]. С.М. Маркедонов, А.А. Озеров, О.В. Рвачева рассматривают возрожденческий процесс как ситуацию социального и социокультурного конструирования $[13 ; 14 ; 20]$. Весьма интересной представляется точка зрения М.А. Рыбловой на возрожденческий процесс как на ситуацию культурной трансформации казачества, характерной чертой которой является возврат к архаичным культурным и организационным формам [21].

Нужно отметить, что все представленные точки зрения имеют серьезное обоснование и позволяют объяснять те или иные стороны возрожденческого процесса. Их применение зависит от рассматриваемого матери- 
ала и целей, которые автор ставит перед собой. В контексте представляемого материала наиболее плодотворным автору представляется рассмотрение возрожденческого процесса как ситуации самовосстановления казачества, когда у определенной части потомков казаков возникло желание заявить о себе.

Цель данной статьи - выявить специфику начального этапа формирования движения за возрождение казачества, его организационных форм, определить ключевые идеи движения, а также раскрыть интерес общественности к данному феномену.

Исследователи возрожденческого феномена не раз отмечали, что движение за возрождение казачества вырастало на основе военно-исторических клубов, которые активно создавались и развивались в СССР в середине 1980-х годов. В том числе во второй половине 1980-х гг. создаются первые военноисторические клубы с казачьей тематикой: «Лейб-гвардии Казачий полк» (г. Ленинград), военно-историческое объединение «Кубанский казачий клуб» (1989 г., г. Краснодар), «Донской военно-исторический клуб» (ДВИК, 1986 г., г. Ростов-на-Дону) [26]. В военно-исторические клубы приходили прежде всего энтузиасты, занимавшиеся реконструкцией событий военной истории, униформы, историей военных частей.

Так, Донской военно-исторический клуб, учрежденный 12 октября 1989 г., в качестве целей своей деятельности определял популяризацию военной истории донского казачества, проведение униформированных походов. Клуб состоял из двух отделов. Первый - военно-историческая комиссия (художники, коллекционеры, историки), второй - униформированное подразделение - Донская казачья дивизия, в составе которой члены клуба принимали участие в униформированных праздниках [16, с. 20].

Создатели Кубанского казачьего клуба им. А.Ф. Бурсака, учрежденного 1 июля 1990 г., также первоначально в качестве целей деятельности провозглашали «...привлечение единомышленников, пропаганда истории кубанского казачества, его униформы, овладение навыками фехтования и джигитовки, участие в военно-униформированных мероприятиях» $[6$, с. 58$]$. Клуб состоял из конной и исторической секции. Участники клуба проводили униформированные походы, а также пропагандировали конное искусство казаков и горцев [6, с. 66].

Военно-исторические клубы находились в сфере внимания ряда крупных советских общественных организаций, таких, например, как Всесоюзное общество «Знание» или Всероссийское общество охраны памятников истории и культуры (ВООПИиК) $[15$, с. 8$]$. На роли ВООПИиК в развитии казачьего движения следует остановиться более подробно. Начавшееся в середине 1960-х гг. как мощное стихийное движение, в основе которого лежал живой интерес к сохранению истории и культуры своей страны, к концу 1980-х гг. ВООПИиК, по мнению Т.В. Таболиной, превратилось в заформализованную структуру, деятельность которой «вырождалась в посиделки с эстетскими разговорами» [24, с. 44]. Наиболее активные члены ВООПИиК понимали, что нужна была новая идея, «которая могла зацепить человека за душу и дать импульс к действиям» [24, с. 45]. Так родилась концепция новой формы организационной работы - землячества, в рамках которых идея сохранения культурного наследия, культурных традиций должна была получить осмысленное и деятельное выражение.

Именно землячество стало первой организационной формой потомков казаков. В 1989 г. Г.Л. Немченко, который являлся членом редколлегии журнала «Кубань», на вечере встречи с читателями журнала объявил о создании землячества казаков в Москве. Формальной датой рождения землячества казаков в Москве считается 5 января 1990 года. На призыв сформировать землячество казаков откликнулись прежде всего те выходцы из казачьих земель, которые представляли интеллигенцию, писатели, журналисты, историки; «всех их заботило одно - как объединить и поднять казаков» $[24$, с. 46]. К концу 1989 г. казачье землячество, объединив потомков казаков разных казачьих войск, стало самым многочисленным в Москве.

Известие о создании в Москве землячества казаков стало катализатором процессов, которые разворачивались в регионах. То, что движение за возрождение казачества во многом являлось результатом общественной ини- 
циативы, отчетливо показывает анализ ситуации в регионах. На Юге России на территориях традиционного проживания казачества в конце 1980-х - начале 1990-х гг. казачьи организации и общественные организации, в деятельности которых так или иначе просматривается казачья тематика, стремительно растут и действуют.

В Ростовской области идеи возрождения казачества, возрождения и сохранения его культуры, реабилитации казачества и т. п. активно развивают и пропагандируют такие организации, как Литературное товарищество «Шолоховский круг» (создано в 1989 г.), «Историко-культурный клуб “Думенковцы-Мировновцы”», «Областной общественный комитет по восстановлению памятника М.И. Платову», «Культурно-историческое общество “Вешенский станичный круг”», историко-культурное общество «Стародонье», «Центр традиционной культуры донских казаков» и др. [15, c. 16]. Ведущую роль в данных организациях играла интеллигенция: члены Союза писателей, сотрудники журналов и газет, литераторы, работники телевидения и др. На основе всех вышеперечисленных организаций в Ростовской области постепенно оформляется движение за возрождение казачества.

В 1990 г. на территории Волгоградской области также формируются казачьи организации. В 1990 г. в области возникло пять крупных казачьих организаций. Это: Второй Донской округ, Хоперский округ, Усть-Медведицкий округ, Волгоградский округ донских казаков и Волжский округ донских казаков. При этом первые три организации возникли на территориях районов, которые до советского периода являлись территориальными структурами Области Войска Донского и даже имели те же названия. Таким образом, закреплялась историческая преемственность современных казачьих организаций с их историческими прототипами [19].

В формировании и последующей работе этих казачьих обществ принимали участие энтузиасты из разных социальных сред. Например, один из атаманов Хоперского округа подчеркивал, что в организации хоперского казачества принимали участие люди разных возрастов и профессий, среди которых были председатели исполкома Урюпин- ского горсовета и Урюпинского райсовета, председатель колхоза, главный редактор газеты «Урюпинская правда», директор школы и др. [1, с. 9]. В воспоминаниях участников первых казачьих организаций почти всегда отмечается, что движение рождалось на волне энтузиазма и его создатели были воодушевлены возможностью воссоздавать казачество: «Круги проходили в полностью забитых залах. От желающих выступить не было отбоя. Каждый старался подбросить инициативу поважнее» [1, с. 19].

Схожие процессы происходили в Краснодарском крае. Как уже было сказано, первой казачьей организацией в Краснодаре стал Кубанский казачий клуб. В его создании принимали активное участие представители интеллигенции: преподаватели и студенты исторического факультета Кубанского государственного университета, журналисты, сотрудники музеев, художники. В письмах-заявлениях о приеме в клуб люди нередко объясняли свое желание следующим образом: «...Прошу Вас принять меня в число казаков, в связи с тем, что я русский человек, православный христианин, желаю служить родной Кубани...» [6, с. 87]. Таким образом, в основе стремления стать членом казачьего клуба лежала память о своих казачьих корнях, желание вспомнить и возродить казачьи обычаи, вновь почувствовать себя казаком, как их предки. Помимо историков и музейных работников, в клуб стали приходить сотрудники правоохранительных органов, руководители предприятий, рабочие, пенсионеры [6, с. 87].

В 1990 г. движение за возрождение казачества начинает набирать силу. Кроме Кубанского казачьего клуба в 1990 г. появлялись и другие казачьи организации. В августе 1990 г. было образовано Пашковское казачье общество, в июне 1990 г. учреждена Кубанская казачья ассоциация, в июле 1990 г. прошел съезд верхнекубанского казачества и создана организация Верхнекубанского казачьего округа [9, л. 28].

О начале возрожденческого процесса в Ставропольском крае первый атаман ставропольского казачества П.С. Федосов вспоминал, как в 1989 г. после встречи с поэтом В. Ходаревым он спросил, нет ли у того желания создать общественную казачью организацию, 
на что тот ответил, что «у него уже давно возникла такая мысль» (цит. по: [23, с. 8]). В инициативную группу, которая стала заниматься вопросами возрождения казачества в крае, вошли представители творческой интеллигенции, представители профсоюзов, журналисты, инженеры, агрономы, офицеры МВД, пенсионеры [23, с. 10].

Впервые казачий круг на территории Ставропольского края был проведен 8 июня 1990 г. в станице Зеленчукской. На круге была создана общественная казачья организация «Верхнекубанский казачий отдел». В Ставропольском крае к осени 1990 г. насчитывалось 57 казачьих организаций.

В конце 1989 г. - начале 1990 г. стали создаваться первые организации терских казаков. 23 марта 1990 г. в г. Владикавказе проводился круг (съезд) терских казаков, который учредил общественную организацию «Терское казачество». Ее атаманом избирался потомственный казак станицы Тарской Герой Советского Союза В.Д. Коняхин.

В Астраханской области, по сравнению с другими регионами Юга России, движение за возрождение казачества началось сравнительно поздно, первые организации, занимавшиеся историко-культурными вопросами астраханского казачества, были созданы в 1991 году. Связано это было с тем, что казачье движение в Астраханской области было малочисленно и развивалось медленно. Фактором активизации казачьего возрождения в Астраханском регионе стало создание организации всероссийского масштаба «Союз казаков» в Москве. В июле 1991 г. атаману «Союза казаков» А.Г. Мартынову пришло письмо от организаторов казачьего возрождения в Астраханской области Ю.П. Русанова и А.Ф. Милейковской. Письмо содержало просьбу помочь в организации казачьего движения, в частности энтузиасты казачьего возрождения писали: «Для нас главный вопpoc - с чего начать?.. Какая должна быть организационная группа, и чем она должна заниматься?» [10, л. 38].

Как и в других регионах, активную роль в возрождении астраханского казачества сыграла интеллигенция. В сентябре - октябре 1991 г. сотрудниками Астраханского краеведческого музея А.Ф. Милейковской, Т. Кара- вацкой, Е.В. Казаковой, специализировавшимися на истории астраханского казачества, создается Казачье культурно-историческое общество. Еще одна казачья организация Астраханское областное культурное общество «Казачий круг» под руководством Ю.П. Русанова - также появилась в 1991 году. Первый круг астраханского казачества прошел в Кремлевском соборе Успения Пресвятой Богородицы в октябре 1991 году. Было принято решение создать казачью общественную организацию [3, с. 319]. В ноябре 1991 г. состоялся «сход» казаков Астраханской области, на котором было заявлено о создании общественной организации Астраханского союза казаков. На Круге был принят Устав организации и избран первый атаман, которым (наверное, впервые за всю историю казачества) стала женщина - А.Ф. Милейковская.

Как вспоминает Е.А. Переловский, стоявший у истоков казачьего возрождения в Астраханской области: «...Казаки, вступившие в общину, были люди разных возрастов, разных профессий: военнослужащие, врачи, учителя, преподаватели, рабочие и т. д. Приходили в общество пообщаться, поговорить...» [18].

Начавшийся в 1990 г. процесс возрождения казачества на территории Республики Калмыкия, как и в других регионах, был связан с сохранившимся у потомков казаков-калмыков воспоминанием о своем казачьем происхождении, желанием заявить о себе, вернуть себе место в истории.

Делегация казаков-калмыков в составе М.Г. Дженгурова, К.П. Шовунова и К.Н. Илюмжинова присутствовала на Большом Учредительном круге Союза казаков в Москве в июне 1990 года. К.Н. Илюмжинов был избран в правление Союза казаков и возглавил посольскую палату [11, с. 775]. После возвращения из Москвы в Элисту М.Г. Дженгуров и К.П. Шовунов выступили по радио с обращением к потомкам казаков о созыве казачьего круга, который был проведен в августе 1990 года.

В июне 1990 г. в Москве созывается Большой Учредительный круг, на котором объявили о создании Союза казаков. На круге присутствовало 263 делегата от уже существовавших на тот момент казачьих организаций, объединявших около 70 тыс. казаков [5, 
c. 8]. В течение 1990 г. казачье движение организационно оформилось практически на всех территориях традиционного проживания казачества на Юге России. В августе 1990 г. создается Союз казаков Калмыкии, в сентябре прошел Учредительный круг ставропольского казачества и была создана общественная организация «Ставропольский краевой союз казаков» (СКСК), в октябре - Кубанская казачья Рада, в ноябре - Союз казаков Области Войска Донского (СКОВД), организационная дата Владикавказского Круга терского казачества - 1991 год.

Явный интерес к казачеству со стороны общественности, на наш взгляд, был продиктован прежде всего объективной ситуацией системного кризиса Советской страны, проявившегося в том числе в области социокультурной идентичности. Такая идентичность, как «советский человек», «советский народ», была разрушена, поиск новой идентичности приводил нередко к возрождению таких архаичных форм, как, например, дворянские общества. Потомки казаков в определенном смысле оказались в более благоприятной ситуации, так как им не нужно было придумывать новую идентичность. Таким образом, казачество стало для определенной части бывших советских граждан (прежде всего потомков казаков) привлекательной социокультурной формой, имевшей прочную историческую основу.

В русле поиска идентичности обращение отдельного человека и социальной общности к истории имеет ключевое значение, так как дает возможность «приобщиться к корням», сформировать определенное представление о своем прошлом и определиться с тем, как себя воспринимать в настоящем. Так, например, создатель конной секции Кубанского казачьего клуба А. Берлизов, объясняя смысл конной подготовки и организации конных походов для современных потомков казаков, говорил, что это «...возможность вести настоящий казачий образ жизни. Конные переходы по горам в казачьей форме... это вам не в манеже сменой ездить» (цит. по: [6, с. 68]). А активный участник казачьего возрождения в ставропольском регионе в 1990-х гг. В.В. Ходарев отмечал, что «мы плохо знаем историю казачества, свои обычаи, культуру. Мы это поте- ряли и потому плохо воспитываем детей...» (цит. по: [23, с. 21]).

В отношении потомков казаков история казачества, его прошлое имели особое значение. В период социалистической модернизации 1920-1930-х гг. казачество не только теряет свой статус военно-служилого сословия его социокультурная система в целом серьезно трансформируется, часто под воздействием репрессивных мер. Развитие казачества, таким образом, было насильственно прервано, что породило у потомков казаков стремление возродить это прошлое. Как следствие, сохранение и возрождение казачьей истории и культуры - одна из главных идей движения за возрождение казачества. Историко-культурная тема красной нитью проходит через формулировки целей и задач всех казачьих организаций, которые создавались в начале 1990-х гг. на начальном этапе возрожденческого процесса. История и культура рассматриваются как инструменты, при помощи которых можно надстроить прошлое в настоящем и прожить его заново. Важнейшими задачами казачьих организаций, в той или иной форме нашедшими отражение практически во всех уставных документах, являются восстановление исторической правды о казачестве, возрождение, пропаганда и сохранение культуры и традиций казаков.

Таким образом, история как поле деятельности и как инструмент - важная составляющая часть казачьего возрожденческого процесса. Например, на Большом Учредительном круге СКОВД принимается «Положение о возрождении исторических обычаев и традиций Войска Донского». В Структуре СКОВД должен был работать Военно-исторический отдел, а также формировались военно-исторические клубы, которые должны были заниматься реконструкторской деятельностью, проводить униформированные походы и, помимо этого, развивать военно-прикладные виды спорта [7, с. 79-80].

Еще одна идея возрождения, часто встречающаяся в документах казачьих организаций и связанная с историей - восстановление исторической справедливости, - напрямую была связана с трагическими событиями казачьей истории периода становления советского государства. Историческая трагедия ка- 
зачества была воспринята потомками казаков как геноцид, в итоге казачество, как особая культурно-этническая группа, было причислено к репрессированным народам и вошло в Закон о реабилитации репрессированных народов.

Восстановление исторической справедливости в отношении казаков предполагало не только его правовую реабилитацию, но и социальную, публичную реабилитацию, связанную с признанием военных заслуг казачества перед Отечеством, роли защитников Российского государства. Таким образом, восстановление исторической справедливости не только позволяло вернуть из исторического забвения казаков и сделать их важнейшим феноменом российской истории, но и фактически создавало новый образ казаков в современной России.

В связи с этим еще одна идея казачьего возрождения - возобновление служения казаков своему Отечеству. Возникновение этой идеи связано с теми политическими процессами, которые развиваются в нашей стране в начале 1990-х годов. По мнению Т.В. Таболиной, объединение казаков в единую организацию - Союз казаков - объяснялось уже тогда желанием сохранить разваливающуюся страну $[24$, с. 49]. Представители казачьих организаций в начале 1990-х гг. постоянно манифестировали стремление патриотического служения России, устранение угрозы ее распада, в том числе и через сплочение казачества. Из Обращения Совета атаманов Союза казаков Области Войска Донского (1991 г.): «...Само понятие “казак” сегодня - это прежде всего человек, борющийся за общероссийские и общегосударственные интересы, за сохранение и процветание нашей страны...» (цит. по: [17, с. 285]). Среди кубанского казачества также доминировала идея возрождения России, а в задачи казачества входили защита Отечества, наведение порядка, борьба с противоправной деятельностью мигрантов и с миграцией в ее негативных формах, защита интересов местного населения, и прежде всего казаков $[24$, с. 20$]$. Атаман ставропольского казачества П.С. Федосов заявлял: «Мы не можем отказаться от несения службы, направленной на обеспечение порядка и стабильности на территории края» (цит. по: [23, с. 24]).
Квинтэссенцией всех целевых установок казачьих организаций можно считать Декларацию казачества, принятую в 1993 г. на Совете атаманов Союза казаков, в которой говорилось: «казаки - многомиллионный народ, сформировавшийся в России много веков назад... История казачества последних четырех веков - это пример служения Российскому государству...»; «Одобряя участие представителей казачества во всех сферах жизни страны... следует подчеркнуть основную обязанность казаков - оборонять Отечество. Казачество рассматривает себя как составную часть сил и средств обеспечения безопасности Российского государства...» (цит. по: [9, c. 234, 236]).

Упоминание в Декларации казачества как «многомиллионного народа» и, что самое важное, законодательное занесение казаков в число репрессированных народов позволяют определить еще одну идею казачьего возрождения - этническое или этнокультурное возрождение казачества.

Впервые четкая формулировка этой идеи появилась в Уставе Общероссийской общественной организации «Союз казаков» (1990 г.), где говорилось, что целью Союза является возрождение казачества как самобытной, исторически сложившейся культурноэтнической общности людей (цит. по: [5, с. 11]).

Идея этнического возрождения, также, как и идея воссоздания исторического прошлого, коррелировала с задачей возрождения/ сохранения культуры казачества. Т.В. Таболина отмечала, что на Учредительном круге Союза казаков в 1990 г. в качестве приоритетных задач организации фигурировала «необходимость обращения к духовным и культурным ценностям, а конкретно - восстанавливать храмы, казачьи святыни, кладбища, создавать казачьи музеи, вести архивную работу» [24, с. 49].

Следует отметить, что, как правило, тема этнического возрождения казачества присутствует в документах тех казачьих организаций, которые формировались на традиционно казачьих территориях, имели более или менее однородный состав (например, донские или кубанские казаки) и, самое главное, социальную основу данных организаций составляли потомки тех казачьих сообществ, история 
формирования которых начиналась без участия государства. Традиционно к таким казачьим сообществам Юга России относят донских и терских казаков. Несмотря на то, что кубанское казачество было создано государством на основе черноморского (бывшего запорожского) казачества и переселенных на кубанскую линию во второй половине XIX в. представителей различных социальных групп, впоследствии переведенных в состояние казаков, его этническая характеристика очень ярко проявилась еще в начале $\mathrm{XX}$ в., а современная манифестация этничности проявлялась, пожалуй, даже сильнее, чем у донцов.

Особо следует сказать о постановке целей и задач возрожденческого процесса в казачьих организациях Астраханской области и Республики Калмыкия. Как уже говорилось, в Астраханской области движение за возрождение казачества началось позже, чем в других регионах Юга России, в связи с тем, что астраханское казачество в большей степени, чем кубанское или донское, подверглось «размыванию» и фактически исчезло в советский период.

Кроме того, Астраханское казачье войско формировалось под воздействием государства в соответствии с его задачами и было относительно молодым войском, формальной датой его основания называют 1817 г. [2, с. 18]. В среде астраханского казачества этнические характеристики не успели сложиться. Таким образом, несмотря на то, что организации астраханского казачества формировались на традиционных территориях проживания и составляли их в основном астраханские казаки (хотя были и выходцы из других казачьих земель), основные задачи астраханские казаки видели в сохранении истории и культуры казаков.

Особенность казачьего возрождения в Республике Калмыкия с точки зрения его этно- и социокультурных характеристик проявилась в намерениях участников движения в начале 1990-х гг.: «Противники возрождения казачества мотивируют свои доводы тем, что новое движение разъединяет калмыцкий народ, способствует возникновению улусизма... Сторонники казачьего возрождения доказываю обратное. Они говорят: калмыки-казаки это прежде всего калмыки, неотъемлемая часть калмыцкого народа. Один язык, одна история, одна культура. Просто казаки хотят возродить обычаи, традиции своих предков, в какой-то мере образ жизни, мышления, свой свободолюбивый дух, вернуться к истокам, чтобы черпать в них силу в это трудное время» $[27$, с. 2].

Таким образом, среди части калмыков, точнее среди калмыков-бузавов, которые до начала советского периода входили в состав донского казачества, сохранившиеся воспоминания о своем казачьем происхождении и мобилизация исторической памяти в 1990-х гг. способствовали формированию движения за возрождение казачества.

Итак, если говорить о специфике развития казачьего движения на Юге России, то можно, на наш взгляд, выделить следующие особенности этого явления. Во-первых, движение развивается очень быстро, о чем говорит и численный рост казачьих организаций, и число участников движения. Во-вторых, развитие движения можно охарактеризовать как стихийный процесс, обусловленный как объективной ситуацией социально-политического кризиса в стране, так и желанием потомков казаков вернуть утраченные связи с прошлым своих предков-казаков, восстановить историческую правду о казаках, и даже в какой-то мере сконструировать новую историю, в которой образ казака-патриота, опоры и защитника Отечества доминировал бы над всем остальным. В-третьих, несмотря на то, что государство сыграло очень большую роль в развитии казачьего возрождения, все же, на наш взгляд, движение прежде всего основывалось на инициативе «снизу», исходившей от потомков казаков. И, наконец, в-четвертых, основными идеями казачьего возрождения можно назвать возрождение и сохранение истории и культурного своеобразия казачества, утверждение патриотического служения казачества в настоящем времени и возрождение казачества как народа. Несмотря на значительные изменения в казачьем возрождении, связанные с формированием государственной и иной службы казачества, которые начнутся во второй половине 1990-х гг., эти идеи в основе своей сохраняются в казачьих обществах, поддерживая дальнейшее развитие казачества. 


\section{РЕГИОНОВЕДЕНИЕ}

\section{СПИСОК ЛИТЕРАТУРЫ}

1. ХХ лет Хоперскому округу. Краткая история возрождения Хоперского казачьего округа. Урюпинск : [б. и.], 2010. - 77 с.

2. Агафонов, О. В. На службе России / О. В. Агафонов // Родина. - 2004. - № 5. - С. 17-22.

3. Антропов, О. О. Астраханское казачество. На переломе эпох / О. О. Антропов. - М. : Вече, 2008. $-416 \mathrm{c}$.

4. Астапенко, Г. П. Возрождение казачества как процесс социальной реконструкции / Г. П. Астапенко // Возрождение казачества (история, современность, перспективы) : тезисы докладов, сообщений, выступлений на V Международной (Bceроссийской) научной конференции. - Ростов н/Д : Логос, 1995. - С. 14-15.

5. Батырев, В. Д. Союз казаков России: 19902000 / В. Д. Батырев, А. И. Изюмов, О. В. Матвеев. М. : РУСАКИ, 2000. - 192 c.

6. Бурмагин, А. Г. От Кубанского казачьего клуба к Кубанской казачьей раде. Краткая история начала возрождения кубанского казачества 19891992 гг. / А. Г. Бурмагин. - Краснодар : Пульс-Софт, 2009. $-320 \mathrm{c}$.

7. Водолацкий, В. П. Возрождение: Первый круг казаков Дона / В. П. Водолацкий, А. А. Озеров, А. Г. Киблицкий. - Ростов н/Д : ИИЦ «Дончак», 2006. - С. 66-92.

8. Водолацкий, В. П. Казачий Дон: очерки истории и культуры : учеб. пособие / В. П. Водолацкий, А. П. Скорик, Р. Г. Тикиджьян ; под ред. проф. А. П. Скорика. - Ростов н/Д : Терра, 2005. - 448 с.

9. Государственный архив Краснодарского края (ГАКК). - Ф. Р-1843. - Оп. 1. - Д. 2. - Неопубликованный.

10. Государственный архив Российской Федерации (ГАРФ). - Ф. 10144. - Оп. 1. - Д. 22. - Неопубликованный.

11. Илюмжинов, Н. Д. Память живая : Документальная и художественная проза / Н. Д. Илюмжинов. - М. : Худож. лит., 2009. - 796 с.

12. Козлов, А. И. Возрождение казачества: история и современность (эволюция, политика, теория) / А. И. Козлов. - Ростов н/Д : Изд-во Рост. ун-та, 1995. - $248 \mathrm{c}$.

13. Маркедонов, С. М. Феномен российского неоказачества / С. М. Маркедонов // Социально-политическая ситуация на Кавказе: история, современность, перспективы. - М. : [б. и.], 2001. - С. 107-119.

14. Озеров, А. А. Конструктивистский подход к исследованию казачества / А. А. Озеров // Философия права. - 2006. - № 3 (19). - С. 69-74.

15. Озеров, А. А. Политико-правовая институционализация современного казачества / А. А. Озеров. - Ростов н/Д : Изд-во Рост. ун-та, 2006. - 162 с.
16. Озеров, А. А. Возрождение казачества в новой России (Социально-философский аспект) / А. А. Озеров, А. Г. Киблицкий-Ростов н/Д : Ростиздат, 2004. - 304 c.

17. Озеров, А. А. Союз казаков Области Войска Донского. Войсковой атаман М.М. Шолохов (История и современность донского казачества) : Исследования и документы / А. А. Озеров, А. Г. Киблицкий. - Ростов н/Д : Ростиздат 2002. $464 \mathrm{c}$.

18. Переловский, Е. А. Воспоминания о начальном этапе возрождения астраханского казачества / Е. А. Переловский // Вестник Астраханского казачьего войска. - Электрон. текстовые дан. Режим доступа: http://vestnikakv.ru/article.php? mode $=$ view\&site $\mathrm{id}=46 \&$ own $\_$menu $\mathrm{id}=15748$. Загл. с экрана.

19. Рвачева, О.В.Казачьи организации Волгоградской области в конце XX - начале XXI века / О. В. Рвачева // Вестник Волгоградского государственного университета. Серия 4, История. Регионоведение. Международные отношения. - 2008. № 1 (13). - С. 43-50.

20. Рвачева, О. В. Казачество в ХХІ в.: возрождение традиций или конструирование нового феномена? / О. В. Рвачева // Очерки истории и культуры казачества Юга России : коллективная монография / под ред. Г. Г. Матишова, И. О. Тюменцева. Волгоград : Изд-во Волгогр. фил. ФГБОУ ВПО РАНХиГС, 2014.-С. 382-404.

21. Рыблова, М. А. Социокультурные трансформации на Дону (XVI-XXI вв.) / М. А. Рыблова // Казачество России: прошлое и настоящее : сб. науч. ст. Вып. 2. - Ростов н/Д : Изд-во ЮНЦ РАН, 2008. - C. 3-32.

22. Скорик, А. П. Казачья корпорация на Дону как современный социальный проект / А. П. Скорик // Клио. - 2006. - № 1 (32). - С. 167-176.

23. Ставропольский краевой союз казаков. Ставропольское казачье войско, 1990-2010 / сост. Д. В. Стригунов, П. Д. Деев. - Ставрополь : Сервисшкола, 2010. - 348 c.

24. Таболина, Т. В. Казаки: драма возрождения, 1980-1990-е годы / Т. В. Таболина. - М. : [б. и.], 1999. $-252 \mathrm{c}$.

25. Трут, В. П. Казачество: происхождение, сущность, реалии, перспективы / В. П. Трут. - [Б. г. : б. и.]. -31 с.

26. Турусов, В. П. Особенности военно-исторического движения в России по опыту ряда отечественных клубов / В. П. Турусов. - Электрон. текстовые дан. - Режим доступа: http://www.avitcentre.spb.ru/exb/06/30/a4.htm. - Загл. с экрана.

27. Цеджинов, С. Союз казаков: трудностям вопреки / С. Цеджинов // Известия Калмыкии. 1992. - 1 апр. (№ 59). 


\section{REFERENCES}

1. XX let Khoperskomu okrugu. Kratkaya istoriya vozrozhdeniya Khoperskogo kazachyego okruga [20 Years to the Khoper District. Short History of Revival of the Khoper Cossack District]. Uryupinsk, 2010.77 p.

2. Agafonov O.V. Na sluzhbe Rossii [On Service of Russia]. Rodina, 2004, no. 5, pp. 17-22.

3. Antropov O.O. Astrakhanskoe kazachestvo. Na perelome epokh [Astrakhan Cossacks. On the Turn of Eras]. Moscow, Veche Publ., 2008. 416 p.

4. Astapenko G.P. Vozrozhdenie kazachestva kak protsess sotsialnoy rekonstruktsii [Revival of the Cossacks as a Process of Social Reconstruction]. Vozrozhdenie kazachestva (istoriya, sovremennost, perspektivy). Tezisy dokladov, soobshcheniy, vystupleniy na $V$ mezhdunarodnoy (vserossiyskoy) nauchnoy konferentsii [The Revival of the Cossacks (History, Present, Prospects). Abstracts of Papers, Reports, Performances at the 5th International (AllRussian) Scientific Conference]. Rostov-on-Don, Izdvo NMTs "Logos", 1995, pp. 14-15.

5. Batyrev V.D., Izyumov A.I., Matveev O.V. Soyuz kazakov Rossii: 1990-2000 [Union of Cossacks of Russia: 1990-2000]. Moscow, RUSAKI Publ., 2000. $192 \mathrm{p}$.

6. Burmagin A.G. Ot Kubanskogo kazachyego kluba k Kubanskoy kazachyey rade. Kratkaya istoriya nachala vozrozhdeniya kubanskogo kazachestva 1989-1992 gg. [From the Kuban Cossack Club to the Kuban Cossack Rada. Short History of the Beginning of Revival of the Kuban Cossacks in 19891992]. Krasnodar, Puls-Soft Publ., 2009. 320 p.

7. Vodolatskiy V.P., Ozerov A.A., Kiblitskiy A.G. Vozrozhdenie: Pervyy krug kazakov Dona [Revival: First Circle of Don Cossacks]. Rostov-on-Don, Donchak Publ., 2006, pp. 66-92.

8. Vodolatskiy V.P., Skorik A.P., Tikidzhyan R.G. Kazachiy Don: ocherki istorii i kultury: Uchebnoe posobie [Cossack Don: Sketches of History and Culture: Manual]. Rostov-on-Don, Terra Publ., 2005. $448 \mathrm{p}$.

9. Gosudarstvennyy arkhiv Krasnodarskogo kraya [State Archive of the Krasnodar Region], F. R-1843, Op. 1, D. 2. (unpublished source).

10. Gosudarstvennyy arkhiv Rossiyskoy Federatsii [State Archive of the Russian Federation], F. 10144, Op. 1, D. 22. (unpublished source).

11. Ilyumzhinov N.D. Pamyat zhivaya: Dokumentalnaya i khudozhestvennaya proza [Memory Is Live: Documentary and Art Prose]. Moscow, Khudozhestvennaya literature Publ., 2009. $796 \mathrm{p}$.

12. Kozlov A.I. Vozrozhdenie kazachestva: istoriya i sovremennost (evolyutsiya, politika, teoriya) [Revival of the Cossacks: History and the Present (Evolution, Policy, Theory)]. Rostov-on-Don, Izd-vo Rost. un-ta, 1995. 248 p.

13. Markedonov S.M. Fenomen rossiyskogo neokazachestva [Phenomenon of the Russian Neocossacks]. Sotsialno-politicheskaya situatsiya na Kavkaze: istoriya, sovremennost, perspektivy [SocioPolitical Situation in the Caucasus: History, Present, Prospects]. Moscow, 2001, pp. 107-119.

14. Ozerov A.A. Konstruktivistskiy podkhod k issledovaniyu kazachestva [Constructivist Approach to the Cossacks Research]. Filosofiya prava, 2006, no. 3(19), pp. 69-74.

15. Ozerov A.A. Politiko-pravovaya institutsionalizatsiya sovremennogo kazachestva [Political and Legal Institutionalization of the Modern Cossacks]. Rostov-on-Don, Izd-vo Rost. un-ta, 2006. $162 \mathrm{p}$.

16. Ozerov A.A., Kiblitskiy A.G. Vozrozhdenie kazachestva $v$ novoy Rossii (Sotsialno-filosofskiy aspekt) [Revival of the Cossacks in New Russia (Social and Philosophical Aspect)]. Rostov-on-Don, Rostizdat Publ., 2004. 304 p.

17. Ozerov A.A., Kiblitskiy A.G. Soyuz kazakov Oblasti Voyska Donskogo. Voyskovoy ataman M.M. Sholokhov (Istoriya i sovremennost donskogo kazachestva). Issledovaniya i dokumenty [Cossacks Union of the Don Cossack Host. Army Ataman M. M. Sholokhov (History and the Present of the Don Cossacks). Research and Documents]. Rostov-onDon, Rostizdat Publ., 2002. 464 p.

18. Perelovskiy E.A. Vospominaniya o nachalnom etape vozrozhdeniya astrakhanskogo kazachestva [Memories About the Initial Stage of Revival of the Astrakhan Cossacks]. Vestnik Astrakhanskogo kazachyego voyska. Available at: http://vestnikakv.ru/ article.php?mode=view\&site id=46\&own menu id $=15748$.

19. Rvacheva O.V. Kazachyi organizatsii Volgogradskoy oblasti v kontse XX - nachale XXI veka [The Cossack Organizations of the Volgograd Region at the End of the 20th - Beginning of the 21st Century]. Vestnik Volgogradskogo gosudarstvennogo universiteta. Seriya 4, Istoriya. Regionovedenie. Mezhdunarodnye otnosheniya [Science Journal of Volgograd State University. History. Area Studies. International Relations], 2008, no. 1 (13), pp. 43-50.

20. Rvacheva O.V. Kazachestvo v XXI v.: vozrozhdenie traditsiy ili konstruirovanie novogo fenomena? [The Cossacks in the 21st century: Revival of Traditions or Designing of a New Phenomenon?]. Matishov G.G., Tyumentsev I.O., eds. Ocherki istorii i kultury kazachestva Yuga Rossii: kollektivnaya monografiya [Essays on the History and Culture of the Cossacks of Southern Russia: Collective Monograph]. Volgograd, Izd-vo Volgogradskogo filiala RANKhiGS, 2014, pp. 382-404. 


\section{РЕГИОНОВЕДЕНИЕ}

21. Ryblova M.A. Sotsiokulturnye transformatsii na Donu (XVI-XXI vv.) [Sociocultural Transformations in the Don Region (16th-21st Centuries)]. Kazachestvo Rossii: proshloe i nastoyashchee: Sbornik nauchnykh statey. Vyp. 2 [The Cossacks of Russia: the Past and the Present: Collected Articles. Vol. 2]. Rostov-on-Don, Izd-vo YuNTs RAN, 2008, pp. 3-32.

22. Skorik A.P. Kazachya korporatsiya na Donu kak sovremennyy sotsialnyy proekt [The Cossack Corporation in the Don Region as a Modern Social Project]. Klio, 2006, no. 1 (32), pp. 167-176.

23. Strigunov D.V., Deev P.D. Stavropolskiy kraevoy soyuz kazakov. Stavropolskoe kazachye voysko. 1990-2010 [Stavropol Regional Union of Cossacks. Stavropol Cossack Army. 1990-2010]. Stavropol, Servisshkola Publ., 2010. 348 p.
24. Tabolina T.V. Kazaki: drama vozrozhdeniya. 1980-1990-e gody [Cossacks: Drama of Revival. 19801990s]. Moscow, 1999. 252 p.

25. Trut V.P. Kazachestvo: proiskhozhdenie, sushchnost, realii, perspektivy [Cossacks: Origin, Essence, Realities, Prospects]. 31 p.

26. Turusov V.P. Osobennosti voennoistoricheskogo dvizheniya $v$ Rossii po opytu ryada otechestvennykh klubov [Features of the Military and Historical Movement in Russia by Experience of a Number of Domestic Clubs]. Available at: http://www. avit-centre.spb.ru/exb/06/30/a4.htm.

27. Tsedzhinov S. Soyuz kazakov: trudnostyam vopreki [Union of Cossacks: Contrary to the Difficulties]. Izvestiya Kalmykii, 1992, no. 59, April 1.

\section{Information About the Author}

Olga V. Rvacheva, Candidate of Sciences (History), Associate Professor, Department of Public Administration and Political Science, Volgograd Branch of the Russian Presidential Academy of National Economy and Public Administration, Gagarina St., 8, 400131 Volgograd, Russian Federation, olgarvacheva@mail.ru.

\section{Информация об авторе}

Ольга Владимировна Рвачева, кандидат исторических наук, доцент кафедры государственного управления и политологии Волгоградского филиала Российской академии народного хозяйства и государственной службы при Президенте Российской Федерации, ул. Гагарина, 8, 400131 г. Волгоград, Российская Федерация, olgarvacheva@mail.ru. 